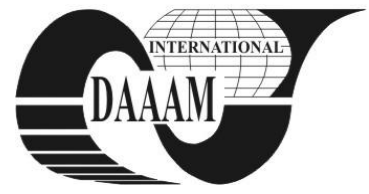

\title{
REPORTING AND REGISTRATION THE ACCOUNTANCY OF THE FEE ON ADDED VALUE
}

\author{
TUREAC, C[ornelia]; PUSCA, A[ndy]; PUSCA, F[lorentina] \& FILIP, A[lin] C[onstantin]
}

\begin{abstract}
In this article we discussed the implementation of the fiscal inspection taking into account the way of calculation, registration and its registration in the accountancy of the tax on added value. The research method is materialized in making the analysis based on the accounting data from within a company and in using literature of specialty. At the economic agents at which the state, directly or through an institution or public authority, has the quality of shareholder, usually, the financial control precedes the tax inspection. To avoid the parallel or repeated controls each direction keeps a strict evidence of the shares of financial control, for each economic agent at which the state directly or through an institution or public authority has the quality of shareholder.
\end{abstract}

Key words: fiscal inspection, registration, accountancy, authority, tax

\section{INTRODUCTION}

The tax on added value it is a tax which covers all phases of the economic circuit, namely production, services and distribution to the final sales by including the final consumers (Bistriceanu, 2007). In terms of the state budget the value added tax is an indirect tax which is established on the operations concerning the transfer of goods of properties and on the provision of services. (Soroceanu, 2005)

It is a unique tax which is perceived in fractionates way corresponding to the added value at each stage of the economic circuit (Duma 2005). The fiscal bodies are those who control how are complied the legal rules, to calculate late payment penalties for overdue payments and to impose fines for constant violations which are a contravention. (Mutascu 2005)

The economic agents who are carrying out taxable operations are obliged to ensure the necessary conditions to issued the documents, information processing and leading the evidence provided by the regulations in the VAT domain, an those which ahs as main activity, retail, hotel activities, services providers to the population have the obligation to install the marking devices which to meet the requirements for applying the tax on added value. (Nicolau, 2009)

\section{RESEARCH METHOD}

The research method is materialized in carrying out the analysis made by the authority of fiscal inspection based on the accounting data of within the company and using the literature of specialty.

The fiscal inspection was made as a result of the address issued by the Administration of Public Finances, Risk Analysis Risk, in the view of resolving the VAT return with refund option afferent to the January 2009, in sum of 10.877 Ron, registered at the Municipal Public Finances Administration.

In accordance with the provisions OMF no. 1857/2007 concerning the Methodology of solving the returns with negative amounts of tax on added value with refund option, the
Administration of Public Finances Galati, the Bureau analysis of the negative returns of VAT proposes the VAT refund after the fiscal inspection.

The fiscal inspection took place in the period 15 16.03.2010 at the headquarter Galati and was registered in the Unique Register of Control on page 4, position 21.

The society was checked on line by the tax on added value, by the authorities of fiscal inspection from within D.G.F.P. Galati A.I.F, SIF, materialized verification through the Report of Fiscal Inspection, which included the December 2009, after which there weren't established additional amounts. The fiscal inspection body informed the taxpayer rights and obligations that he is having during the fiscal inspection.

\section{RESULTS}

Commercial Society Mepro Cons LLC has as main activity "Manufacture of metal constructions and component parts of the metallic structures", CAEN code 2511 - General Mechanical Operations, Certificate issued on 2/27/2008.

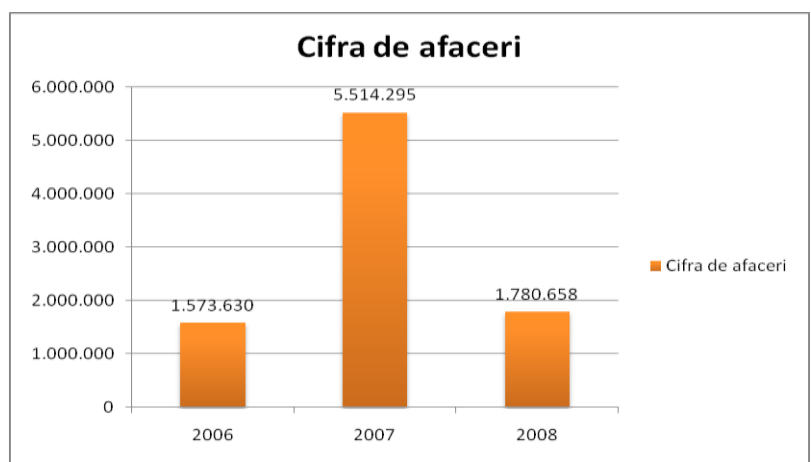

Fig. 1. The turnover during $2006-2008$

As it can be seen from the chart above the most fruitful year was 2007 with 5.514,295 Ron

\subsection{The VAT}

Verified period of VAT it was $01-31.01 .2010$. The fiscal period is the calendar month, in accordance with the provisions of art. 1561 , alin (1) of the Law nr. 571/2003 regarding the Fiscal Code, amended and supplemented;

Mepro Cons LLC Galati has recorded payer of tax on added value, by choice, since 01.09 .2002 . The main activity of the society is in manufacturing metallic confections which are commercialized in Norway, has in heritage fixed assets, to achieve the object of activity, respective, welding machines, inverters, lathes, cutting machine with ferast blade, synergic pro welding installation, grinders, etc, and a number of 11 employees, with which it operates. (Donath 2004)

In the period $01-31.01 .2010$, the society has registered the tax on added value as follows: VAT collected $=1$ leu 
VAT deductible $=10.878$ Ron

Recoverable VAT 31.12.2009 $=10.877$ Ron

Required at reimbursement through the return nr. 17248/ 24.02.2010

\subsection{Collected VAT}

To determine accurately, the tax on added value, there were verified the sale journals, invoices and other specific documents from which to result the tax on collected added value, recorded by the economic agent. (Vacarel 2006)

In the period $01-31.01 .2010$ the society recorded total revenues in the amount of $148.371,93$ Ron, achieving the following: taxable transactions: The economic agent has registered expenditure concerning the differences of exchange rate in red amounting 7 Ron, from the leasing facture nr. 0253379/24.01.2010, for which it was, collected VAT in the amount of 1 leu.

Free operations: The revenues from export in the total amount of $148.181,70$ Ron, the equivalent of $35.984,16$ euro, obtained from the deliveries of metallic confections, respective pieces of square pipe, of plate, columns of HEA, diesel tank 1500 liters, 3000 liters, 6000 liters, performed with the society's employees in Romania, based on the contract nr. C08/003/17.09.2008, completed with the company Procut Norway, representing operations free of VAT, according to the previsions art 143, alin (1), a letter of the Law nr. 571/2003 regarding the Fiscal Code, as amended and supplemented.

We mention that the economic agent has made at the date 28.01.2010 the facture GLMEP nr 510 of advance cancellation in the amount $36.652,10$ Ron, the equivalent $8.671,35$ euros, the facture which cancels the facture nr. 508/23.12.2009. The factures invoiced by the suppliers were recorded chronologically in the accountancy, in the period at which is referred.

During the verified period, the society has collected and declared VAT in the amount of 1 leu.During the verification the authority of fiscal inspection has completed the Sheet of analysis of the tax on collected added value.

\subsection{Deductible VAT}

For the period 01-31.01.2010, deductible Vat registered in the accountancy and declared by the society is in the amount of 10.878 Ron. From the presented documents to the team of fiscal inspection, it was found that the deducted VAT in the amount of 111 Ron, from the fiscal fuel receipts, for which the economic agent has not presented the roadmaps from which to result that the transport means which have consumed this fuel circulated only to the interests of the society.

Also, the tax receipts were not stamped and registered the name of the buyer and the registration number of the vehicle.

Thus there were violated the previsions art 146, alin (2) of the Law nr. 571/2003, concerning the Fiscal Code, amended and supplemented and the point 46 (2) of the H.G. nr. 44/2004, to approve the Methodological Norms for Applying the Law no. 571/2003 regarding the Fiscal Code.

During the verification the authority of fiscal inspection has completed the Sheet of analysis of the tax on deductable added value. According to this, Mepro Cons LLC Galati, registered unpaid suppliers in the total amount of 25558, 28 Ron.

\subsection{Tax on added value to refund}

The society registers VAT to be recovered in the sum of 10.877 Ron, according to the verification balance drawn for the January 2010. On 31.01.2010, Mepro Cons LLC, registers a negative balance account of VAT of 10.877 Ron, amount requested at refund through the expense account of submitted VAT at the AFFP Galati under nr. 17249/24.02.2010.
As a result of the fiscal inspection, the VAT situation is presented as follows:

VAT requested at refund $=10.877$ Ron Admitted VAT to refund $=10.766$ Ron

According to the previsions of the art 1473, alin (6) of the Law nr. 571/2003 regarding the Fiscal Code, Title IV - Tax on added value, the economic agent is entitled to reimbursement of the tax on added value in the amount of 10.766 Ron. The authorities of Fiscal inspection have completed the Sheet of analysis of the negative amount of VAT.

\section{CONCLUSIONS}

The authorities of financial control can require more explanations of the representative of whether employee of the economic agent, which to contribute at establishing some relevant elements of the activity of the economic agent, which can influence the verbal process of financial control. The refusal to answer at questions will be registered in the verbal process of financial control and there will be applied penalties provided by the law.

The fiscal inspection is carried out based on the principles of independence, uniqueness, autonomy, hierarchy, territoriality and decentralization.

At the completion of the fiscal inspection, the taxpayer is obliged to give a written statement on own responding, from which to result that there were at the disposition all the required documents and information for the fiscal inspection. In the declaration it will be mentioned and the fact that there were returned all the requested documents and made available for the taxpayer.

During the verified period, the society has collected and declared VAT in the amount of 1 leu. During the verification the authority of fiscal inspection has completed the Sheet of analysis of the tax on collected added value.

For the period 01-31.01.2010, deductible Vat registered in the accountancy and declared by the society is in the amount of 10.878 Ron

From the presented documents to the team of fiscal inspection, it was found that the deducted VAT in the amount of 111 Ron, from the fiscal fuel receipts, for which the economic agent has not presented the roadmaps from which to result that the transport means which have consumed this fuel circulated only to the interests of the society. Also, the tax receipts were not stamped and registered the name of the buyer and the registration number of the vehicle.

\section{REFERENCES}

Bistriceanu, Gh. (coord), (2007), Little Encyclopedia of Finance, Curency, Insurance, Universitara Publishing House, ISBN 9789737490841, Bucharest, vol.1

Donath Liliana (2004), Public Finances and elements of tax administration, ISSN 1841-7779Ed. Marineasa, Timisoara, 2004.

Duma, Florin. (2005), Public Finances - Course Notes, UBB Cluj, 2005

Mutascu Mihai (2005), Public Finances, Ed. Augusta \& Artpres, ISBN 973-7836-07-3 Timisoara

Nicolau Mihaela, (2009), Fiscality - Course Notes, Danubius University, Galati

Soroceanu, Mircea (2005), Taxes, Fees and Contributions, Ed. Junimea, ISBN 973-46-0045-, Iasi

Vacarel, Iulian s.a. (2006), Public Finances, Didactic and Pedagogic Publishing House, ISBN 9789733019985, Bucharest

Voinea, Gh.(2006), Fiscal Legislation - Course Notes, „Al. I. Cuza" University, ISBN 978-3-540-74497-9 Iasi 